\title{
Optimalisasi Supervisi Akademik sebagai Upaya untuk Meningkatakn Kinerja Guru dalam Menerapkan Model Pembelajaran Contextual Teaching and Learning (CTL) di SDN 58/X Teluk Majelis Tahun Ajaran 2021/2022
}

\author{
Peri \\ SDN 58/X Teluk Majelis \\ Desa Teluk Majelis, Tanjung Jabung Timur, Jambi, Indonesia \\ peri@gmail.com
}

\begin{abstract}
This study aims to obtain information and discuss academic supervision as an effort to improve teacher performance in implementing the contextual teaching and learning (CTL) learning model at SDN 58/X Teluk Majelis. This research is school action research which consists of two cycles by following four stages, namely planning, implementation, observation, and reflection. This research was carried out at 58/X Teluk Majelis with the subject of 16 teachers consisting of class teachers and subject teachers which took place in the odd semester of the 2021/2022 academic year. Data were collected using observation sheets, field notes and documentation and analyzed using percentages and data reduction. The results show that academic supervision can improve teacher performance in implementing the contextual teaching and learning (CTL) learning model at SDN 58/X Teluk Majelis by giving rewards.
\end{abstract}

Keywords: Teacher Performance, CTL, Academic Supervision

\begin{abstract}
Abstrak
Penelitian ini bertujuan untuk mendapatkan informasi dan membahas tentang supervisi akademik sebagai upaya untuk meningkatakn kinerja guru dalam menerapkan model pembelajaran contextual teaching and learning (CTL) di SDN 58/X Teluk Majelis. Penelitian ini merupaka penelitian tindakan sekolah yang terdiri dari dua siklus dengan mengikuti empat tahapan yaitu perencanaan, pelaksanaan, observasi dan refleksi. Penelitian ini dilaksanakan di 58/X Teluk Majelis dengan subjek guru-guru sebanyak 16 orang terdiri dari guru kelas dan guru mata pelajaran yang berlangsung pada semester ganjil tahun ajaran 2021/2022. Data dikumpulkan menggunakan lembar observasi, catatan lapangan dan dokumetasi serta dianalisis menggunakan persentase dan reduksi data. Hasil penelitian menunjukkan bahwa supervisi akademik sebagai dapat meningkatakn kinerja guru dalam menerapkan model pembelajaran contextual teaching and learning (CTL) di SDN 58/X Teluk Majelis dengan tindakan memberikan reward.
\end{abstract}

Kata kunci: Kinerja Guru, CTL, Supervisi Akademik

Copyright (c) 2022 Peri

Corresponding author: Peri

Email Address: peri@gmail.com (Desa Teluk Majelis, Tanjung Jabung Timur, Jambi)

Received 10 January 2022, Accepted 20 January 2022, Published 31 January 2022

\section{PENDAHULUAN}

Kompetensi guru merupakan faktor pertama yang dapat mempengaruhi keberhasilan pembelajaran. Guru bertanggung jawab untuk mengatur, mengarahkan dan menciptakan suasana yang dapat mendorong peserta didik untuk melaksanakan kegiatan-kegiatan di dalam kelas. Guru yang memiliki kemampuan tinggi akan bersikap kreatif dan inovatif yang selamanya akan mencoba dan mencoba menerapkan berbagai penemuan baru yang dianggap lebih baik untuk pembelajaran siswa. Secara umum, kompetensi guru dapat diklasifikasi menjadi kompetensi pedagogik, kompetensi profesional, kompotensi personal, dan kompetensi sosial yang diperoleh melalui pendidikan profesi (Ilfiandra, 2016). Dengan demikian diharapkan proses pembelajaran yang dilaksanakan guru, dapat 
dicapai tanpa pemborosan waktu, tenaga, material, finansial, dan bahkan pemikiran sehingga pada gilirannya tujuan sekolah dapat dicapai secara efektif dan efisien.

Dalam usaha untuk memperbaiki dan meningkatkan proses pembelajaran yang dilakukan oleh guru, kepala sekolah bertugas menyelenggarakan serta melaksanakan kegiatan supervisi. Tugas ini cukup penting karena melalui peran supervisor, kepala sekolah dapat memberi bantuan, bimbingan, ataupun layanan kepada guru dalam menjalankan tugas ataupun dalam memecahkan permasalahan yang dihadapi pada saat proses pembelajaran (Suradi, 2018). Secara umum, kompetensi guru dapat diklasifikasi menjadi kompetensi pedagogik, kompetensi profesional, kompotensi personal, dan kompetensi sosial yang diperoleh melalui pendidikan profesi (Ilfiandra, 2016).

Peranan guru sangat menentukan karena kedudukannya sebagai pemimpin pendidikan di antara peserta didik dalam suatu kelas. Kadang-kadang guru mulai mengajar dengan hanya mendiktekan saja pelajarannya dan jika masih ada waktu baru memberikan penjelasan sekedarnya tidak mencerminkan pembelajaran CTL apa lagi tanpa variasi dengan penggunaan media yang sesuai maupun sumber-sumber belajar yang memadai.

Berdasarkan hasil pengamatan yang dilakukan oleh penelit didapat bahwa faktor penyebabnya adalah kebanyakan guru-guru kurang menguasai pembelajaran CTL dan keterampilan penggunaan media serta sumber belajar yang ada sehingga pembelajaran yang mereka laksanakan masih didominasi dengan cara mentrasfer dari pada menciptakan pembelajaran yang memberi kesempatan siswa untuk mengkonstruksi pengetahuannya.Berdasarkan uraian di atas, tampak bahwa model dan strategi pembelajaran yang tepat akan berdampak positif bagi siswa.

Kenyataan yang ada di sekolah tempat peneliti bertugas sebagai kepala sekolah menunjukkan hal yang terbalik. SDN 58/X Teluk Majelis yang merupakan sekolah binaan peneliti, bila ditelusuri lebih lanjut, faktor yang meyebabkan guru belum mampu melaksanakan strategi pembelajaran dengan tepat karena kinerja menyusun strategi model pembelajaran CTL belum optimal, bahkan ada yang tidak membuat. Penerapan model CTL pembelajaran sangat penting, karena perencanaan yang baik berpengaruh terhadap hasil belajar siswa. Oleh karena itu diperlukan adanya perubahan paradigma dalam melaksanakan pembelajaran yang semula guru berpikir bagaimana mengajar menjadi berpikir bagaimana siswa belajar.

Untuk mengatasi maslah tersebut peneliti mengatasinya dengan melakukan supervisi akademik. Supervisi akademik termasuk bagian dari supervisi pengajaran. Dikatakan supervisi akademik karena prosedur pelaksanaannya lebih ditekankan kepada mencari sebab-sebab atau kelemahan yang terjadi dalam proses belajar mengajar, dan kemudian secara langsung pula diusahakan bagaimana cara memperbaiki kelemahan atau kekurangan tersebut. Tujuan supervisi akademik adalah mengembangkan profesionalisme, memotivasi guru, dan meningka tkan kualitas pembelajaran (Kemdiknas, 2011:6).

Untuk melaksanakan supervisi akademik secara efektif diperlukan keterampilan konseptual, interpersonal dan teknikal (Glickman dalam Masnun, 2017). Oleh sebab itu, setiap pengawas sekolah 
Optimalisasi Supervisi Akademik sebagai Upaya untuk Meningkatakn Kinerja Guru dalam Menerapkan Model Pembelajaran Contextual Teaching and Learning (CTL) di SDN 58/X Teluk Majelis Tahun Ajaran 2021/2022, Peri 633

harus memiliki keterampilan teknikal berupa kemampuan menerapkan teknik-teknik supervisi yang tepat dalam melaksanakan supervisi akademik. Kompetensi guru yang mampu mengubah mindsetnya terlihat pada tahap-tahap pembelajaran (Usman, 2002). Pelaksanaan supervisi akademik oleh pengawas sekolah dapat meningkatkan proses pembelajaran jika dilakukan sesuai dengan prinsipprinsip yang berlaku. Oleh karena itu, kepala sekolah sebagai supervisor dituntut untuk mampu melakukan supervisi akademik bagi guru-guru dalam meningkatkan proses pembelajaran. Berdasarkan permasalah di atas peneliti mengadakan penelitian yang bertujuan untuk mendapatkan informasi dan membahas tentang optimalisasi supervisi akademik sebagai upaya untuk meningkatakn kinerja guru dalam menerapkan model pembelajaran contextual teaching and learning (CTL) di SDN 58/X Teluk Majelis tahun ajaran 2021/2022.

Kinerja merupakan terjemahan dari kata performance (job performance). Performance terbentuk dari kata perform yang berarti to do an action or piece of work. Dari kata ini muncul kata performance yang berarti how well person, machine, etc, does a piece of work or an activity. Dengan demikian, kinerja merupakan tindakan menampilkan atau melaksanakan suatu kegiatan. Kinerja sering juga diartikan penampilan kerja. Secara inplisit, dalam UU No 20 tahun 2003 dan UU No 14 tahun 2005 telah memberikan gambaran bahwa kinerja guru berada dalam rumusan melaksanakan tugas utama dan menunaikan beban kerja, serta mewujudkan kompetensi dalam mengemban amanah pendidikan yang ada di pundaknya.

Syamsir Torang menyatakan bahwa Kinerja (performance) adalah kuantitas dan atau kualitas hasil kerja individu atau sekelompok di dalam organisasi dalam melaksanakan tugas pokok dan fungsi yang berpedoman pada norma, standar operasional prosedur, kriteria dan ukuran yang telah ditetapkan atau yang berlaku dalam organisasi (Torang, 2012:118). Kinerja adalah hasil kerja suatu organisasi dalam rangka mewujudkan tujuan strategik, kepuasan pelanggan dan kontribusi terhadap lingkungan strategik. Secara sepintas kinerja biasa diartikan sebagai prilakuberkarya, berpenampilan atau hasil karya (Akdon, 2009:166). Kinerja dalam tujuan psikologis adalah proses tingkah laku seseorang sehingga menghasilkan suatu yang menjadi tujuan pekerjaanya. Perbedaan kinerja antara orang satu dengan orang lain dalam mencapai apa yang dituju, menurut Maler, merupakan akibat adanya perbedaan karakteristik individu. Orang yang sama dapat menghasilkan kinerja yang berbeda, dengan demikian kinerja dapat dipengaruhi oleh dua faktor yaitu individu dan faktor situasi (Naomi, 2001:1). Kinerja Guru menurut Sumiyati (2002:3) adalah kemampuan pokok yang diamati selama proses pembelajaran berlangsung. Diperjelas lagi oleh Nurdin (2002:86) bahwa kinerja guru dalam kegiatan pembelajaran meliputi 3 unsur pokok, yaitu: Kinerja guru dalam mendesain pembelajaran, kinerja guru dalam melaksanakan pembelajaran, kinerja guru dalam menilai pembelajaran.

Dari uraian di atas dapat disimpulkan bahwa kinerja adalah penampilan kerja yang telah dicapai oleh seseorang. Kinerja merupakan hasil akhir dari suatu aktifitas yang telah dilakukan seseorang untuk meraih suatu tujuan. Pencapaian hasil kerja ini juga sebagai bentuk perbandingan hasil kerja seseorang dengan standar yang telah ditetapkan. Apabila hasil kerja yang dilakukan oleh 
seseorang sesuai dengan standar kerja atau bahkan melebihi standar maka dapat dikatakan kinerja itu mencapai prestasi yang baik.

Guru mempunyai tanggungjawab untuk melihat segala sesuatu yang terjadi dalam kelas untuk membantu proses perkembangan siswa. Jasmani (2013: 155) mengemukakan istilah kinerja berasal dari kata job performane atau actual performance (prestasi kerja atau prestasi sesungguhnya yang dicapai oleh seseorang). Hal ini dapat diartikan bahwa kinerja merupakan prestasi yang nampak sebagai bentuk keberhasilan kerja seseorang. Senada dengan yang dikemukakan dalam Peraturan Menteri Pendidikan Nasional Republik Indonesia Nomor 35 Tahun 2010 tentang Petunjuk Teknis Pelaksanaan Jabatan Fungsional Guru dan Angka Kreditnya, kinerja guru adalah hasil penilaian terhadap proses dan hasil kerja yang dicapai guru dalam melaksanakan tugasnya.

Secara umum, faktor yang mempengaruhi kinerja dapat dikelompokkan menjadi dua yakni faktor fisik dan non fisik. Faktor fisik meliputi sarana prasarana, fasilitas, pergedungan, dan sebagainya. Faktor non fisik mencakup suasana hati, adanya motivasi, suasana kerja, dan sejenisnya. Kondisi lingkungan fisik sangat mempengaruhi kondisi karyawan dalam bekerja. Selain itu, kondisi lingkungan fisik juga akan mempengaruhi berfungsinya faktor lingkungan non fisik. Kinerja seorang pegawai akan baik, jika pegawai mempunyai keahlian yang tinggi, kesediaan untuk bekerja, adanya imbalan atau upah yang layak dan mempunyai harapan masa depan. Semua faktor itu berpadu dalam sebuah aktivitas untuk menghasilkan suatu produk (Sulthon, 2010:27).

Faktor-faktor yang mempengaruhi kuantitas dan kualitas kinerja individu maupun organisasi, Syamsudin menemukan tiga faktor yang dapat mempengaruhi kinerja (performance) individu, yaitu: keterampilan, pengalaman, dan kesanggupan. Pendapat lain menjelaskan delapan faktor yang mempengaruhi kinerja individu dalam organisasi, yaitu: kompetensi, kemauan, energi, teknologi, kepemimpinan, kompensasi, kejelasan tujuan dan keamanan (Torang, 2012:119).

Menurut Wilson (2000:135), kinerja (performance) guru adalah kemampuan yang didasari pengetahuan, sikap, keterampilan, dan motivasi dalam menghasilkan sesuatu. Faktor utama yang mempengaruhi kinerja adalah "kemampuan dan kemauan". Kinerja anggota organisasidi dalam suatu institusi adalah hasil perpaduan antara kemampuan, komitmen terhadap profesi danmotivasi berprestasi tinggi. Artinya, prestasi kerja para anggotaorganisasi dapat didorong agar lebih meningkat dalamrangka upaya mencapai tujuan yang diinginkan.

Masalah kinerja dalam organisasi dapat ditimbulkan oleh banyakfaktor. Faktor ini dapat dikelompokkan menjadi empat penyebab utamamasalah-maslah kinerja berikut ini (Marwansyah, 2012:234).1) Pengetahuan atau keterampilan, karyawan tidak tahu bagaiamana menjalankan tugastugas secara benar kurangnya keterampilan, pengetahuan atau kemampian. 2) Lingkungan, maslah tidak berhubungan dengan karyawan, tetapi disebabkan oleh lingkungan kondisi kerja, proses yang buruk, dan lain-lain.3) Sumber daya, kurangnya sumber daya atau teknologi. 4) Motivasi, karyawan tahu bagaimana menjalankan pekerjaan, tetapi tidak melakukan secara benar. Ini munggkin saja disebabkan oleh proses seleksi yang tidak sempurna. 
Dari beberapa pendapat yang telah di uraikan diatas dapat disimpulkan bahwa kinerja guru dapat dipengaruhi oleh adanya faktor internal dan eksternal. Faktor internal meliputi: Sikap mental (motivasi kerja, disiplin kerja, etika kerja), pandangan hidup (kepercayaan, teologis), kompetensi kerja (kemampuan dan keterampilan kerja, jenjang pendidikan), kejujuran amanah (dapat dipercaya) dan keikhlasan.

Menilai kinerja guru adalah suatu proses menentukan tingkat keberhasilan guru dalam melaksanakan tugas-tugas pokok mengajar dengan menggunakan patokan-patokan tertentu. Bagi para guru, penilaian kinerja berperan sebagai umpan balik tentang berbagai hal seperti kemampuan, kelebihan, kekurangan dan potensinya. Bagi sekolah hasil penilaian para guru sangat penting arti dan perannya dalam pengambilan keputusan.

Contextual Teaching and Learning (CTL) adalah sebuah sistem atau pendekatan dalam proses pembelajaran yang pertama kali diperkenalkan oleh Elaine B. Johnson. Pendekatan ini telah banyak digunakan karena terasa lebih efektif dan dan dapat mencapai sasaran dengan lebih baik. Menurut Johnson (2006:67): "Sistem CTL adalah sebuah proses pendidikan yang bertujuan menolong para siswa melihat makna di dalam materi akademik yang mereka pelajari dengan cara menghubungkan subjek-subjek akademik dengan konteks dalam kehidupan keseharian mereka. Untuk mencapai tujuan ini, sistim tersebut meliputi delapan komponen berikut: membuat keterkaitan-keterkaitan yang bermakna, melakukan pekerjaan yang berarti, melakukan pembelajaran yang diatur sendiri, melakukan kerja sama, berfikir kritis dan kreatif, membantu individu untuk tumbuh dan berkembang, mencapai standar yang tinggi, dan menggunakan penilaian autentik".

Mohammad Jauhar (2011: 181) menyatakan bahwa Contextual Teaching Learning (CTL) merupakan proses pembelajaran yang holistik dan bertujuan membantu siswa untuk memahami makna materi ajar dengan mengaitkannya terhadap konteks kehidupan mereka sehari-hari (konteks pribadi, sosial dan kultural), sehingga siswa memiliki pengetahuan/ keterampilan yang dinamis dan fleksibel untuk mengkontruksi sendiri secara aktif pemahamannya. Siswa belajar melalui mengalami bukan menghafal, mengingat pengetahuan bukan sebuah perangkat fakta dan konsep yang siap diterima akan tetapi sesuatu yang harus dikontruksi oleh siswa.

Manfaat pendekataan Contextual Teaching and Learning menurut Asis Saefudin (2014: 22) dapat mendorong terciptanya berpikir kritis dan kreatif (critical and creative thinking) di kalangan siswa dalam rangka mengumpulkan, menganalisis, dan menyintesis informasi, guna mencari solusi dan memecahkan masalah. Sesuai pendapat Nasrun (2014: 159) menyatakan bahwa "In addition, contextual teaching and learning is an approach that's help develop student's high cognitive level. Such an approach can also trains the students to think critically and creatively in collecting data, understanding an issue, and solving a problem.” Pada dasarnya pembelajaran kontekstual merupakan pendekatan yang membantu mengembangkan tingkatan kognitif siswa yang tinggi. Selain itu pendekatan ini juga dapat melatih siswa untuk berpikir kritis dan kreatif pada pengumpulan data, memahami isu dan menyelesaikan permasalahan. 
Model pembelajaran Contextual Teaching and Learning (CTL) adalah proses pendidikan yang dapat menolong siswa melihat makna di dalam materi akademik yang mereka pelajari dengan cara menghubungkan materi akademik dengan konteks dalam kehidupan sehari-hari mereka. Trianto (2012: 74) menurut pandangan kontruktivisme menyebutkan anak secara aktif membangun pengetahuan dengan cara terus menerus mengasimilasi dan mengakomodasi informasi baru, dengan kata lain kontruktivisme adalah teori perkembangan kognitif yang menekankan peran aktif siswa dalam membangun pemahaman mereka mengenai realita kehidupan nyata sehingga mampu menciptakan lingkungan belajar yang mendorong siswa mengkonstruk pengetahuan dan keterampilan secara mandiri.

Supervisi merupakan suatu bagian yang penting dalam pendidikan, supervisi mengandung arti yang luas namun intinya sama yaitu kegiatan yang bertujuan untuk memberbaiki proses pembelajaran. Dilihat dari sudut etimologi supervisi berasal dari kata super dan vision yang masing-masing kata itu berarti atas dan penglihatan. Jadi secara etimologis, supervisi adalah penglihatan dari atas. Pengertian itu menurut Subari (1994: 1) merupakan arti kiasan yang menggambarkan suatu posisi yang melihat berkedudukan lebih tinggi dari pada yang dilihat. Seorang supervisor mempunyai posisi dan kedudukan di atas atau lebih tinggi yang bertugas melihat, menilai, mengawasi orang-orang yang disupervisinya dalam menuju suatu perbaikan (Kompri: 2015:193). Menurut (Mukhtar dan Iskandar: 2009:40), secara umum istilah supervisi berarti mengamati, mengawasi, atau membimbing dan menstimulir kegiatan-kegiatan yang dilakukan oleh orang lain dengan maksud untuk mengadakan perbaikan. Konsep supervisi didasarkan atas keyakinan bahwa perbaikan merupakan suatu usaha kooperatif dari semua orang yang berpartisipasi dan supervisor sebagai pemimpin.

Menurut Adams dan Dickey sebagaimana dikutip oleh Sahertian (2000: 17), supervisi adalah program yang terencana untuk memperbaiki pengajaran. Sedangkan Carter dalam Dictinionory of Education menyatakan bahwa supervisi adalah usaha petugas sekolah dalam memimpin guru-guru dan petugas-petugas lainnya dalam memperbaiki pengajaran, termasuk menstimulasi, menyeleksi pertumbuhan jabatan dan perkembangan guru-guru serta merevisi tujuan, tujuan pendidikan, bahan pengajaran serta metode dan evaluasi pengajaran.

Menurut Arikunto (2012), ada tiga ruang lingkup supervisi diterapkan di sekolah, yaitu; a) Supervisi akademik, titik beratkan supervisi mengamati hal-hal yang berkaitan dengan pembelajaran atau akademik, b) Supervisi administrasi; supervisi yang menitik beratkan pengamatan terhadap manajemen administrasi, c) Supervisi lembaga, pengatan dalam supervisi meliputi seluruh manajemen penyelenggaraan sekolah.

Supervisi dalam proses pendidikan menurut Kompri (2017:1) pada dasarnya pelayanan yang disediakan oleh pemimpin untuk membantu guru-guru agar semakin cakap sesuai dengan perkembangan ilmu pengetahuan pada umumnya dan ilmu pendidikan pada khususnya sehingga ia mampu meningkatkan efektivitas proses pembelajaran di sekolah. Menurut Ngalim Purwanto (2012:76) menyebutkan bahwa supervisi akademik adalah segala bantuan dari para pemimpin 
sekolah, yang tertuju kepada perkembangan kepemimpinan guru-guru dan personel sekolah lainnya di dalam mencapai tujuan-tujuan pendidikan.

Berdasarkan pendapat ahli di atas dapat disimpulkan bahwa supervisi akademik adalah proses pemberian bantuan, pengarahan, dan pembinaan, pengajaran yang ditujukan pada perbaikan-perbaikan dan pembinaan aspek pengajaran yang menitik beratkan pengamatan supervisor pada masalahmasalah akademik, yaitu hal-hal yang langsung berada dalam lingkungan kegiatan pembelajaran.

Supervisi akademik mempunyai beberapa tujuan. Salah satu tujuannya adalah membantu guru dalam mengembangkan kompetensinya, mengembangkan kurikulum, mengembangkan kelompok kerja guru, dan membimbing penelitian tindakan kelas (PTK). Selain itu, supervisi akademik memiliki fungsi mendasar dalam keseluruhan program sekolah karena sebagai sumber informasi bagi pengembanganprofesionalisme guru dengan melihat dari hasil pelaksanaan supervisiakademik tersebut (Lantip Diat Prasojo dan Sudiyono,2011:84).

Sudarjat, dkk (2015:148) menyatakan supervisi akademik adalah pembinaan, pengarahan, dan bimbingan untuk peningkatan serta pengembangan kemampuan dan keterampilan guru dalam berkontribusi pada tujuan pendidikan. Indikatornya adalah: 1). Menyusun pengawasan program, 2). Bantuan untuk guru secara individu atau kelompok. 3) Pengembangan profesional guru atau bimbingan 4). Melaksanakan kegiatan pemantauan atau pengawasan. 5). Penilaian kinerja guru. 6). Refleksi atas hasil penilaian, 7). Menggunakan temuan penilaian. 8). Melaporkan hasil pengawasan.

Pelaksanaan supervisi akademik di SDN 58/X Teluk Majelis bertujuan untuk meningkatkan kemampuan guru di sekolah tersebut. Karena menurut kepala sekolahnya, saat ini kemampuan guru di SD itu masih perlu sekali untuk ditingkatkan kualitasnya. Oleh karena itu, diharapakan dengan dijadikannya tempat praktik supervisi akademik, maka akan ada pengaruh positif pada guru-guru yang bertugas saat ini. Selain itu, dapat bermanfaat secara umum pada kualitas pembelajaran yang dilaksanakan.

\section{METODE}

\section{Setting Penelitian}

Penelitian ini merupaka penelitian tindakan sekolah yang terdiri dari dua siklus dengan mengikuti empat tahapan yaitu perencanaan, pelaksanaan, observasi dan refleksi. Penelitian ini dilaksanakan di 58/X Teluk Majelis dengan subjek guru-guru sebanyak 16 orang terdiri dari guru kelas dan guru mata pelajaran yang berlangsung pada semester ganjil tahun ajaran 2021/2022. Data dikumpulkan menggunakan lembar observasi, catatan lapangan dan dokumetasi serta dianalisis menggunakan persentase dan reduksi data.

\section{HASIL DAN DISKUSI}

\section{Siklus I}

1. Perencanaan 
Perencanaan pada siklus I terdiri dari: 1) Menyusun jadwal supervisi, 2) Menyusun instrument, 3) Membuat lembaran catatan lapangan, 4) Menyiapkan agenda supervisi.

\section{Pelaksanaan}

Tahap pelaksanaan siklus I dilaksanakan pada hari Senin, 6 September 2021. Proses supervisi dimulai dengan memberi pengantar tentang maksud pertemuan dan kemudian diikuti oleh uraian singkat tentang hal yang akan dibahas atau kasus tertentu yang akan menjadi bahan pembicaraan. Selesai memberikan pengantar, uraian singkat, atau menginformasikan kasus ini, tanya jawab dimulai. Diskusi yang hangat dan perdebatan mungkin terjadi. Hal itu sangat baik dilakukan asalkan mengarah kepada pemantapan pemahaman tentang hal-hal yang dibahas yang sebelumnya dipandang belum banyak dipahami oleh guru-guru.

Selanjutnya, tindakan supervisi juga dilaksanakan pada rentang waktu mulai dari hari Senin tanggal 13 September sampai dengan hari Selasa tanggal 21 September 2021. Tindakan Peneliti pada pelaksanaan supervisi siklus pertama sebagai berikut. (1) Peneliti memeberikan indikator yang harus dicapai pada saat persiapan, pelaksanaan, dan penilaian seminggu sebelum pelaksanaan supervisi, (2) Peneliti menyuruh guru mengisi format penilaian serta membuat perencanaan kembali kegiatan berikut yang akan disupervisi. Pada tahap ini peneliti supervisi tidak hanya membicarakan materi pelajaran dan proses pembelajaran saja seperti kebanyakan pada supervisi individual, tetapi juga membahas tentang upaya-upaya meningkatkan profesi guru. Upaya yang dimaksud antara lain adalah cara-cara agar guru berdedikasi pada tugasnya, meningkatkan kepribadian, benar-benar belajar seumur hidup, bisa bekerja sama secara baik dengan orang tua siswa, bisa menganalisa kondisi daerah dalam rangka melaksanakan kurikulum lokal, bisa menjadi agen pembaruan masyarakat, dan sebagainya. Peneliti menenkan kepada guru mengebai model pembelajaran contexual teaching and learning (CTL). Peneliti sudah menjelaskan pengertian, ciri-ciri, tujuan dan manfat dari pembelajar CTL ini, dan mengharapkan guru-guru dapat meningkatkan kinerjanya dengan menggunakan model CTL tersebut.

\section{Observasi}

Setelah tahap pelaksanan berikut akan dijelaskan tahapan pengamatan yang dilakukan oleh peneliti selama proses pelaksanaan berlangsung. Hasil pengamatan peneliti yang dibantu oleh observer paa siklus I dapat dilihat pada tabel berikut ini:

Tabel 1. Hasil Pengamatan Kinerja Guru Siklus I

\begin{tabular}{|c|l|c|c|}
\hline No & Komponen CTL & $\%$ & Kategori \\
\hline 1 & Konstruktivisme (Constructivism) & 58 & $\mathrm{C}$ \\
\hline 2 & Inkuiri (Inquiry) & 52 & $\mathrm{C}$ \\
\hline 3 & Bertanya (Questioning) & 62 & $\mathrm{~B}$ \\
\hline 4 & Masyarakat Belajar (Learning Community) & 56 & $\mathrm{C}$ \\
\hline 5 & Pemodelan (Modeling) & 83 & $\mathrm{~A}$ \\
\hline 6 & Refleksi (Reflection) & 62 & $\mathrm{~B}$ \\
\hline 7 & Penilaian Autentik (Authentic Assessment) & 56 & $\mathrm{C}$ \\
\hline
\end{tabular}


Optimalisasi Supervisi Akademik sebagai Upaya untuk Meningkatakn Kinerja Guru dalam Menerapkan Model Pembelajaran Contextual Teaching and Learning (CTL) di SDN 58/X Teluk Majelis Tahun Ajaran 2021/2022, Peri 639

Berdasarkan tabel di atas dapat disimpulkan bahwa kinerja guru dalam menerapkan model pembelajaran contextual teaching and learning (CTL) masih berada pada kategori kurang. Dai 7 komponen pada pembelajaran CTL, komponen pemodelan yang berada pada kategori amat baik, sedangkan selebihnya berada pada kategori baik dan cukup. Pemodelan adalah proses pembelajaran dengan memperagakan sesuatu contoh yang dapat ditiru oleh setiap siswa, dan hal ini dinilai sudah berada pada kategori baik. Proses pembelajaran didasarkan pada pencarian dan penemuan melalui proses berpikir secara sistematis masih kurang. Pengetahuan dan keterampilan yang diperoleh siswa diharapkan bukan hasil mengingat seperangkat fakta-fakta, tetapi hasil dari menemukan sendiri. Pada proses inkuiri ini guru masih menjadi pusata atau teacher centered.

\section{Refleksi}

Tahap refleksi dilaksanakan pada hari Senin tanggal 27 September 2021 yang dibantu oleh seorang observer yang bernama Darman Joni, S,Pd. bertempat di ruangan kepala SDN 58/X Teluk Majelis. Melalui upaya ini diperoleh suatu kesepakatan mengenai keberhasilan dan kegagalan siklus I serta upaya untuk mengatasi agar tidak timbul kegagalan pada hal yang sama di siklus II. mengenai hal itu, yakni sebagai berikut: 1) Setelah siklus I berlangsung, sedikit banyaknya kinerja guru mengalami peningkatan, baik dalam merencanakan pembelajaran maupun melaksanakan pembelajaran berlandaskan model pembelajaran CTL. Hal ini setidaknya telah member dampak positif terhadap proses dan hasil belajar siswa; dan 2) Suatu hal yang masih dipandang kurang baik dan ini merupakan kegagalan dari siklus I, yakni kurang berhasil meningkatkan kinerja guru dalam menumbuhkembangkan karakter yangdiinginkan, baik pada saat eksplorasi, elaborasi, maupun konfirmasi. Hal ini dapat terjadi karena kebiasaan guru dan siswa dalam kegiatan pembelajaran sebelumnya masih dibawa ke kegiatan pembelajaran siklus I. Itu sebabnya, aktivitas belajar siswa kurang mencerminkan karakter model pembelajaran. Sisi lainnya yang kurang direncanakan dengan baik oleh masing-masing guru, yaitu komponen materi pokok pembelajaran, alat dan sumber pembelajaran, dan teknis penilaian pembelajaran. Demikian pun dalam efektivitas waktu, perlu dipertimbangkan agar jangan sampai terjadi lebih banyak digunakan untuk penyajian materi ajar, sehingga kegiatan-kegiatan lainnya yang sama pentingnya kurang difasilitasi waktu yang memadai. Untuk itu pada sklus selanjutnya peneliti berusaha memperbaiki kendala-kendala tersebut agar kinerja guru meningkat serta dengan memberikan reward sebagai tindakan pada siklus II.

\section{Siklus II}

a. Perencanaan

Tahap perencanaan siklus II terdiri dari: 1) Menyusun jawal penelitian, 2) Menyusun instrument penelitian, 3) Membuat agenda supervisi, 4) Peneliti mengidentifikasi permasalahan yang ditemukan, 5) Menyiapkan reward.

b. Pelaksanaan

Tahap pelaksanaan dilaksanakan pada hari Selasa tanggal 5 Oktober 2021. Pada siklus II ini peneliti kembali memberikan materi tentang CTL. Instrumen penelitian pada siklus II tetap 
menggunakan instrumen pada siklus I. Selanjutnya penelitian juga dilaksanakan dalam rentang waktu dimulai pda hari Senin tanggal 11 Oktober 2021 sampai dengan hari Sabtu tanggal 23 Oktober 2021. Tindakan Peneliti pada pelaksanaan supervisi siklus kedua sebagai berikut. (1) Peneliti memeberikan indikator yang harus dicapai pada saat persiapan, pelaksanaan, dan penilaian seminggu sebelum pelaksanaan supervisi. Guru yang disupervisi diajak diskusi tentang format tersebut, (2) Peneliti menyuruh guru mengisi format penilaian yang ingin dicapai, satu minggu sebelum pelaksanaan supervisi, (3) Peneliti mendiskusikan persiapan dengan guru yang akan disupervisi, (4) Peneliti mengamati guru pada saat supervisi dengan cara berkolaborasi secara langsung dalam PBM, (5) Peneliti berdiskusi dengan guru setelah melaksanakan supervisi, (6) Guru dan Peneliti menganalis hasil belajar siswa dan membuat laporan bersama tentang pembelajaran. (7) Guru dan Peneliti menganalisis program yang telah dibuat untuk diperbaiki jika kurang sesuasi.

c. Observasi

Setelah tahap pelaksanan berikut akan dijelaskan tahapan pengamatan yang dilakukan oleh peneliti selama proses pelaksanaan berlangsung. Hasil pengamatan peneliti yang dibantu oleh observer pada siklus II dapat dilihat oada tabel berikut ini:

Tabel 2. Hasil Pengamatan Kinerja Guru Siklus II

\begin{tabular}{|c|c|c|c|}
\hline No & Komponen CTL & $\%$ & Kategori \\
\hline 1 & Konstruktivisme (Constructivism) & 90 & $\mathrm{~A}$ \\
\hline 2 & Inkuiri (Inquiry) & 81 & $\mathrm{~A}$ \\
\hline 3 & Bertanya (Questioning) & 81 & $\mathrm{~A}$ \\
\hline 4 & Masyarakat Belajar (Learning Community) & 77 & $\mathrm{~B}$ \\
\hline 5 & Pemodelan (Modeling) & 96 & $\mathrm{~A}$ \\
\hline 6 & Refleksi (Reflection) & 85 & $\mathrm{~A}$ \\
\hline 7 & Penilaian Autentik (Authentic Assessment) & 85 & $\mathrm{~A}$ \\
\hline
\end{tabular}

Berdasarkan tabel di atas dapat disimpulkan bahaw kinerja guru pada siklus II sudah meningkat dan berada pada kategori baik. Hal ini dapat dilihat dari 7 komponen CTL yang menjadi penilaian dalam penelitian ini dengan rata-rata berada > 60 yang merupakan kategori baik. Hasil pengamatan peneliti menjelaskan bahwa pembelajaran yang pada siklus I bersifat teacher centered, pada siklus II sudah bersifat student centered. Selain itu juga terlihat adanya kegiatan bertanya (questioning). Bertanya adalah cerminan dalam kondisi berpikir. Bertanya dalam pembelajaran dipandang sebagai kegiatan guru untuk mendorong, membimbing, dan menilai kemampuan berpikir siswa. Bagi siswa, kegiatan bertanya dimaksudkan untuk menggali informasi, mengkomunikasikan apa yang sudah diketahui, dan mengarahkan perhatian pada aspek yang belum diketahuinya.

d. Refleksi

Refleksi siklus II dilaksanakan pada hari Senin tanggal 25 September 2021 dibantu oleh seorang observer yang bernama Darman Joni, S.Pd. dan bertempat di ruangan kepala SDN 58/X Teluk Majelis. Berdasarkan hasil diskusi antara peneliti dan observer didapat bahwa kendala-kendala yang terjadi pada siklus I sudah dapat di atasi pada siklus II, sehingga kinerja guru pada siklus II juga 
sudah meningkat. Hal ini juga dengan adanya tindakan pemberian reward. Untuk itu penelitian ini tidak dilanjutkan ke siklus berikutnya.

\section{Diskusi}

Hasil penelitian menunjukkan bahwa melalui supervise klini dapat meningkatkan kinerja guru dalam menggunakan model pembealajaran contextual teaching and learning (CTL). Dengan kinerja yang baik, maka pelaksanaan supervisi yang bersifat instruktif kepada para guru terutama guru yang mengajar kelas dapat mengoptimalkan pemahaman guru terhadap metode mengajar yang inovatif melalui pembinaan secara intensif dengan menerapkan salah satu jenis metode mengajar yaitu model pembelajaran contextual teaching and learning (CTL) sebagai sumber belajarnya. Pembelajaran Kontekstual (CTL) adalah konsep belajar dimana guru menghadirkan dunia nyata kedalam kelas dan mendorong peserta didik membuat hubungan antara pengetahuan yang dimilikinya dengan penerapanya dalam kehidupan mereka sehari-hari, peserta didik memperoleh pengetahuan dan keterampilan dari konteks yang terbatas sedikit demi sedikit, dan dari proses mengkonstruksi sendiri (Muhammad Fathurrohman, 2012:71).

Pembelajaran disekolah tidak hanya difokuskan pada pemberian pembekalan kemampuan pengetahuan bersifat teoretis saja, tetapi bagaimana agar pengalaman belajar yang dimiliki siswa senantiasa terkait dengan permasalahan-permasalahan actual yang terjadi dilingkungannya. Dengan demikian, model pembelajaran CTL adalah keterkaitan setiap materi topik pembelajaran dengan kehidupan nyata. Melalui pemahaman konsep yang benar tentang CTL itu sendiri akan membekali kemampuan para guru menerapkan secara lebih luas, tegas dan penuh keyakinan, karena memang telah didasari oleh kemampuan konsep teori yang kuat.

\section{KESIMPULAN}

Berdasarkan hasil penelitian dan pembahasan dapat disimpulkan bahwa melalui supervise akademik dapat meningkatkan kinerja guru menggunakan model pembelajaran contextual teaching and learning di SDN 58/X Teluk Majelis dengan tindakan memberikan reward. Persentase pembelajaran contextual teaching and learning yang terbentuk dari tujuh indikator pertanyaan yaitu modeling, questioning, lerning community, inquiry, constructivisme, reflection dan authentic assessment. Ketujuh indikator ini menggambarkan pendekatan pembelajaran kontekstual yang semuanya mengalami peningkatan dari siklus I ke siklus II.

\section{UCAPAN TERIMA KASIH}

Ucapan terima kasih sangat layak disampaikan untuk semua pihak yang telah membantu dalam pengerjaan artikel ini. Baik teman, dosen, kakak, dan yang lainnya. Artikel ini dapat dibuat karena adanya bantuan mereka. Semoga artikel ini dapat bermanfaaat untuk banyak pihak. 


\section{REFERENSI}

Abdul Kadim Masaong. (2013). Supervisi Pembelajaran dan Pengembangan Kapasitas. Guru, Bandung: Alfabeta.

Acheson, K.A dan Gall, M.D. (1987). Techniques in the Clinical. Supervisiona of Teache., Second Edition, White Palin, New York: Longman.

Akdon. (2009). Strategic Management for Education Management (Manajemen. Strategik untuk Manajemen Pendidikan). Bandung: Alfabeta

Ali Imron. (2011). Manajemen Peserta Didik Berbasis Sekolah, Jakarta: Bumi. Aksara.

Asis Saefudin dan Ika Berdiati. (2014). Pembelajaran Efektif. Bandung: Remaja. Rosdakarya.

Asmani, Jamal Ma'mur. (2012). Buku Panduan Internalisasi Pendidikan Karakter di. Sekolah. Yogyakarta: Diva Press.

Asra, Sumiati. (2002). Metode Pembelajaran. Bandung: CV. Wacana Prima.

Dewi Ma'rifah. (2004). Pengaruh Motivasi Kerja dan Budaya Organisasi terhadap Kinerja Pegawai Sosial Pada Unit Pelaksana Teknis Dinas Sosial Propinsi Jawa Timur, Jurnal Manajemen dan Kewirausahaan.

Fathurrahman, Muhammad dan Sulistyorini. (2012). Belajar \& Pembelajaran, Meningkatkan Mutu Pembelajaran Sesuai Standar Nasional. Yogyakarta: Teras

Ilfiandra, I., Suherman, U., Akhmad, S. N., Budiamin, A., \& Setiawati, S. (2016). Pelatihan dan Pendampingan Penulisan Karya Tulis Ilmiah Bagi Guru SD. Jurnal Pengabdian Pada Masyarakat, 1(1), 70-81.

Ilyas, Y. (1999). Kinerja: Teori Penilaian dan Penelitian. Jakarta: FKM UI. IQ. Jakarta: PT Gramedia Pustaka Utama

Jauhar, Mohammad. (2011). Implementasi Paikem dari Behavioristik sampai konstruktivistik. Jakarta:

Prestasi Pustakaraya.

Johnson, B. E. (2006). Contextual Teaching And learning. Bandung: PT. Mizan.

Marwansyah. (2012). Manajemen Sumber Daya Manusia. Bandung: Pustaka Setia

Mulyasa. (2007). Standar Kompetensi dan Sertifikasi Guru. Bandung: PT. Remaja. Rosdakarya.

Pidarta, Made. (2009). Supervisi Pendidikan Kontekstual. Jakarta: Rineka Cipta.

Simamora, Henry. (2005). Membuat Karyawan Lebih Produktif Dalam Jangka Panjang. (Manajemen SDM). Yogyakarta: STIE YKPN.

Sinungan, Muchdarsyah. (2003). Produktivitas. Bumi Aksara. Jakarta

Sulthon, H.M. dan M. Khusnuridlo. (2010). Manajemen Pondok Pesantren dalam Perspektif Global. Yogyakarta: Laksbang.

Suradi, A. (2018). Supervisi Akademik Kepala Sekolah Terhadap Kinerja Guru Pendidikan Agama

Islam Di Sekolah Dasar Negeri 79 Kota Bengkulu. Jurnal Pendidikan Dasar Islam, 5(1).

Syaiful, Sagala. (2012). Supervisi Pembelajaran. Bandung: Alfabeta.

Torang, Syamsir. (2012). Metode Riset Struktur Dan Perilaku Organisasi. Bandung: Penerbit Alfabeta 
Optimalisasi Supervisi Akademik sebagai Upaya untuk Meningkatakn Kinerja Guru dalam Menerapkan Model Pembelajaran Contextual Teaching and Learning (CTL) di SDN 58/X Teluk Majelis Tahun Ajaran 2021/2022, Peri 643

Trianto. (2012). Model Pembelajaran Terpadu. (Jakarta: PT Bumi Aksara).

Usman \& Nurdin. (2002). Konteks Implementasi Berbasis Kurikulum. Jakarta: PT. Raja Grafindo Persada.

Yuniarsih Tjuju \& Suwanto. (2011). Manajemen Sumber Daya Manusia. Alfabeta. Bandung. 